\title{
English for Jobseekers: Pelatihan Keterampilan Berbahasa Inggris untuk Anak Muda Pencari Kerja di Rumah Siap Kerja Jakarta
}

\section{English for Jobseekers: English Training to Improve the English Communication Skills for Youth Jobseekers in Rumah Siap Kerja Jakarta}

\author{
Ince Dian Aprilyani Azir \\ Politeknik Negeri Media Kreatif, Jakarta, Indonesia \\ incedian@polimedia.ac.id
}

Riwayat Artikel: Dikirim 16 Agustus 2019; Diterima 18 November 2019; Diterbitkan 30 November 2019

\begin{abstract}
Abstrak
Angka pengangguran muda yang mencapai 43,4 persen menjadi titik tolak Rumah Siap Kerja sebagai pusat pelayanan terpadu untuk kegiatan pelatihan keterampilan kerja dan kewirausahaan. Berbagai pelatihan sudah digelar oleh Rumah Kerja sebagai mitra pengabdi. Hanya saja, salah satu kemampuan yang wajib dimiliki oleh para kaum muda untuk memperoleh pekerjaan yang layak yaitu kemampuan komunikasi berbahasa Inggris belum pernah diadakan kegiatan pelatihan sebelumnya.udah banyak riset yang membuktikan bahwa kemampuan berbahasa Inggris adalah kunci untuk bisa unggul hampir di semua aspek kehidupan manusia. Inisiasi kegiatan pelatihan terhadap kemampuan bahasa Inggris di Rumah Kerja dilaksanakan sebagai solusi peningkatan keterampilan komunikasi Berbahasa Inggris baik secara tertulis maupun secara lisan dalam tujuan khusus untuk mencari pekerjaan. Dalam kegiatan ini, para peserta mendapatkan pengetahuan dan keterampilan membuat profil diri dalam bentuk $\mathrm{CV}$ secara daring dan konvensional juga dalam bentuk media sosial profesional. Selain itu, peserta juga mendapatkan pengetahuan dan pengalaman bagaimana membuat surat lamaran kerja secara konvensional dan elektronik. Tidak hanya itu, peserta juga mendapatkan simulasi praktek wawancara kerja dalam Bahasa Inggris. Simulasi wawancara kerja dengan penulis menjadi kegiatan akhir dari pelatihan ini untuk mengevaluasi hasil pembelajaran para peserta selama pelatihan.
\end{abstract}

Kata kunci: pelatihan, keterampilan, bahasa inggris, pencari kerja, anak muda

\begin{abstract}
The high number of youth unemployment reached 43.4 percent to be the starting point of Rumah Siap Kerja as a hub for job skills and entrepreneurship training activities. Various trainings have been held by the Rumah Siap Kerja as a partner of this training activity. Unfortunately, there has not been any English training conducted in the partner institution while English skills bave been considered as the key to excellence in almost all aspects of human life. This inspires the trainer to provide the training entitled English for Jobseekers as a solution for English communication skills either in writing or orally within the English for specific purpose of seeking jobs. In this activity, participants gain knowledge and skills to create self-identity in the form of online and written $C V$ as well as in the form of professional social media. In addition, participants also gained the knowledge and experience on how to write a cover letter and send it via email based on the email ethics explained by the trainer previously. Moreover, the participants experience the interview practice in English. Simulating a job interview with the author became the final activity of the training to evaluate the participants ' learning outcomes during the training.
\end{abstract}

Keywords: training, skills, english, jobseekers, youth

\section{PENDAHULUAN}

Badan Pusat Statistik (2018) merilis data pengangguran untuk mereka yang berusia 15 - 24 tahun atau yang disebut dengan angkatan muda mencapai 43,4 persen. Rumah Siap Kerja sebagai pusat pelatihan kerja untuk kaum muda hadir sebagai solusi untuk menekan angka pengangguran angkatan muda ini melalui beberapa program seperti pelatihan keterampilan, kewirausahaan, dan beasiswa pendidikan. Sejak dibuka pada beberapa bulan lalu yaitu di bulan April 2019, Rumah Siap Kerja sudah melaksanakan berbagai kegiatan 
pelatihan untuk peningkatan keterampilan kerja untuk anak muda di daerah Jakarta Selatan. Kebanyakan pelatihan yang sudah bekerja sama dengan Rumah Kerja sebagai mitra kegiatan pengabdian ini adalah pelatihan untuk keterampilan soft skills, belum banyak pelatihan teknis dan vokasi (bard skills) yang bisa diikuti oleh anak muda. Hanya saja, salah satu kemampuan yang wajib dimiliki oleh para kaum muda untuk memperoleh pekerjaan yang layak yaitu kemampuan komunikasi berbahasa Inggris belum pernah diadakan. Padahal, sudah banyak riset yang membuktikan bahwa kemampuan berbahasa Inggris adalah kunci untuk bisa unggul hampir di semua aspek kehidupan manusia (Aungwatanakun 1994) (Al-Sibai, 2004) (Richard, 2008). Bahkan untuk memenangkan persaingan global terutama di Kawasan Masyarakat Ekonomi ASEAN, para pekerja dan wirausaha dituntut untuk bisa berkomunikasi dalam Bahasa Inggris agar transaksi perdagangan bisa berjalan dengan lancar antara satu negara dengan negara lainnya dalam Kawasan Asia Tenggara.

Untuk itu, kegiatan pelatihan ini hadir sebagai solusi peningkatan keterampilan komunikasi Berbahasa Inggris baik secara tertulis maupun secara lisan. Pelatihan ini berfokus kepada peningkatan keterampilan komunikasi yang digunakan di dunia professional agar dengan kemampuan Berbahasa Inggris ini para peserta bisa diterima bekerja di industri manapun, tidak hanya di industri skala besar bahkan bisa diterima di perusahaan besar multinasional yang mewajibkan kemampuan berbahasa Inggris kepada setiap karyawannya.

Pengabdian ini hadir pertama kalinya sebagai pelatihan keterampilan berbahasa Inggris (bard skills) dengan metode pendekatan komunikatif yang menitikberatkan pada simulasi praktek berkomunikasi dalam Bahasa Inggris, yang secara spesifik ditujukan untuk peningkatan keterampilan berbahasa Inggris untuk memperoleh pekerjaan yang lebih baik.
Agar peluang diterima di perusahaan yang bonafide menjadi semakin tinggi, pelatihan ini diawali dengan pembuatan profil berbahasa Inggris yang bisa menunjukkan kompetensi dan keahlian para peserta baik secara manual maupun secara elektronik via laman pembuatan CV daring dan media sosial profesional terbesar yang bisa memperbesar peluang mendapatkan informasi pekerjaan. Selain itu, para peserta juga diajarkan bagaimana bahasa dan etika penulisan surat lamaran kerja tidak hanya melalui metode penulisan surat konvensional tetapi juga melalui metode elektronik. Etika pengiriman surat lamaran elektronik juga diajarkan kepada para peserta untuk menunjang pengiriman aplikasi lamaran kerja melalui surat elektronik.

Lie (2007) dan Di Grapello, Kruse, \& Tandon (2011) memaparkan hasil riset yang menginformasikan bahwa para pemberi kerja sangat membutuhkan para pekerja yang tidak hanya terampil di bidangnya saja, tetapi juga sangat terampil dalam komunikasi berbahasa Inggris. Oleh karena itu, pelatihan ini juga diisi dengan materi bagaimana strategi menghadapi wawancara kerja dalam Bahasa Inggris untuk memperbesar peluang diterimanya para peserta untuk bekerja di perusahaan yang mewawancarainya. Materi tidak sebatas bagaimana menjawab pertanyaan wawancara kerja berbahasa Inggris yang sering muncul tetapi juga pada persiapan mental serta persiapan teknis lain yang harus dilakukan oleh para pencari kerja untuk memperbesar peluang diterima bekerja.

\section{METODE}

Metode yang digunakan dalam kegiatan ini lebih banyak ke praktek dibandingkan teori, dikonversikan menjadi 20\% pemaparan teori oleh pemateri dan $80 \%$ simulasi dilakukan oleh para peserta.

Kegiatan Pelatihan Keterampilan Bahasa Inggris untuk Para Pencari Kerja: English for Jobseekers ini dimulai dengan pemaparan materi pembuatan profil 
berbahasa Inggris yang akan menjadi penciri dan filter pertama bagi para penyedia lapangan kerja dalam menyeleksi kandidat pekerja. Profil yang akan dibuat dalam aktivitas simulasi akan ditekankan tidak hanya pada aspek penggunaan tata bahasa dan pilihan kata yang tepat dalam pembuatan profil identitas diri tetapi juga pada aspek etika komunikasi yang persuasif untuk menarik minat pemberi kerja memasukkan peserta dalam calon kandidat potensial. Untuk lebih meyakinkan lagi, para peserta akan dibekali keterampilan membuat profil secara daring melalui media sosial professional Linked In agar profil masing-masing pencari kerja bisa terekam dengan baik.

Setelah profil sudah siap, para peserta diberikan materi melamar pekerjaan dengan menuliskan surat lamaran berbahasa Inggris yang tepat agar memberikan kesan profesional di mata penyedia lapangan kerja. Metode penulisan surat yang diajarkan tidak hanya dalam bentuk surat konvensional tetapi juga dalam bentuk surat elektronik yang ditujukan kepada langsung ke penyedia kerja. Selanjutnya, peserta akan diberikan pengetahuan tentang tata cara menghadapi wawancara kerja berbahasa Inggris mulai dari pertanyaan apa saja yang sering ditanyakan, bagaimana cara menjawab dengan tepat, hingga bagaimana menyiapkan mental untuk bisa diterima bekerja di tempat yang dituju.

Kegiatan pelatihan ini dilaksanakan dengan metode pelaksanaan sebagai berikut:

1. Ceramah

Pemateri memaparkan materi mengenai unsur-unsur penting dan cara pembuatan profil identitas diri (CV) yang menarik. Setelah itu, pemateri menyampaikan bagaimana menulis surat lamaran kerja yang benar. Pemateri juga memberikan materi tentang bagaimana teknik menjawab pertanyaan dalam wawancara kerja secara tepat.

2. Diskusi

Pemateri membuka sesi tanya jawab tentang $\mathrm{CV}$, surat lamaran kerja, dan wawancara kerja saat materi disampaikan. Setelah itu, para peserta juga mendiskusikan $\mathrm{CV}$, surat lamaran kerja, dan lembar jawaban wawancara kerja ke sesama peserta untuk saling memberikan tanggapan dan masukan satu sama lain. Metode diskusi dalam rangka memberikan masukan ke sesama peserta ini dilakukan agar para peserta bisa saling belajar untuk memahami materi yang disampaikan secara lebih baik.

3. Praktek

Para peserta tidak hanya mempraktekkan materi pembuatan $\mathrm{CV}$ secara online lewat laman situs penyedia $\mathrm{CV}$ terstandarisasi tetapi juga menulis $\mathrm{CV}$ secara konvensional sesuai standar Eropa yang dibagikan pemateri. Hal ini bertujuan agar para peserta bisa membiasakan diri untuk membawa serta dokumen saat menghadiri panggilan wawancara kerja. Pemateri menjelaskan bahwa hal ini sangat penting untuk menunjang persiapan dan kepercayaan diri para peserta nantinya. Jika peserta tidak membawa serta dokumen saat wawancara kerja, pemateri menjeleaskan bahwa hal tersebut bisa saja menjadi indikasi bahwa peserta tidak siap untuk menghadiri sesi wawancara kerja bahkan bisa dinilai tidak siap menerima tawaran kerja di instansi atau perusahaan tersebut. Pemateri menjelaskan bahwa seringkali perusahaan menerima banyak aplikasi di tengah kesibukan para personalia sehingga biasanya tidak sempat untuk mencetak semua aplikasi yang masuk, yang jumlahnya bahkan bisa ribuan. Untuk itu, pemateri menjelaskan bahwa pengisian dokumen $\mathrm{CV}$ secara konvensional ini sebagai praktek pembiasaan bahwa peserta harus membawa serta segala dokumen persyaratan atau dokumen penunjang agar lebih siap dan percaya diri saat wawancara. Setelah itu, para peserta diminta membuat akun media sosial profesional untuk memperbesar peluang 
memperoleh pekerjaan. Tanpa surat lamaran kerja, CV tidak akan berarti apaapa untuk memperoleh pekerjaan. Oleh karena itu, pemateri juga memberikan kesempatan ke para peserta untuk menuliskan surat lamaran kerja melalui situs laman penyedia jasa pembuatan surat lamaran kerja secara daring. Peserta juga diminta untuk menuliskan surat lamaran kerja secara langsung di secarik kertas yang telah dibagikan. Hal ini untuk membiasakan peserta membawa surat lamaran kerja saat sesi wawancara kerja. Peserta diinstruksikan untuk selalu membawa lembaran CV dan surat lamaran kerja saat menghadapi wawancara kerja. Sebelum pelatihan ditutup dengan simulasi wawancara kerja, para peserta terlebih dahulu dibagikan panduan daftar pertanyaan wawancara dan maksud pertanyaanpertanyaan tersebut sebenarnya. Para peserta wajib mengisi kolom jawaban sesuai profil masing-masing mengikuti panduan yang ada.

4. Evaluasi

Pemateri memimpin langsung sesi simulasi wawancara kerja dengan berperan sebagai pemberi kerja. Metode ini sekaligus sebagai metode evaluasi pelatihan karena pemateri akan memberikan masukan terhadap CV dan surat lamaran kerja yang telah dibuat oleh para peserta. Selain itu, pemateri mengajukan beberapa pertanyaan saat simulasi wawancara sekaligus sebagai alat evaluasi sejauh mana para peserta memahami daftar pertanyaan dan panduan jawaban yang sudah dibagikan sebelumnya.

\section{HASIL DAN PEMBAHASAN}

Kegiatan pengabdian kepada masyarakat dengan menyasar kaum muda pencari kerja bertajuk "English for Jobseekers" ini dilaksanakan di Ruang Serbaguna Rumah Siap Kerja Jakarta. Peserta adalah kaum muda dari berbagai wilayah Jakarta dan sekitarnya yang baru saja lulus SMA dan juga beberapa lulus kuliah yang saat ini sedang berusaha memperoleh pekerjaan. Beberapa peserta juga telah bekerja dan ikut kegiatan pelatihan ini untuk mendapatkan peluang memperoleh pekerjaan yang lebih baik di kemudian hari.

Dalam sesi diskusi sebelum pelatihan dimulai, para peserta mengakui bahwa motivasi terbesar mengikuti pelatihan adalah ingin belajar bagaimana agar memenangi persaingan memperoleh pekerjaan dengan meningkatkan keterampilan dan kemampuan Bahasa Inggris. Ada beberapa kendala yang dihadapi para peserta dalam berbahasa Inggris dalam rangka mencari pekerjaan misalnya kendala dana mengikuti kursus Bahasa Inggris yang diakui sebagian peserta cukup mahal. Selain itu, peserta juga mengungkapkan bahwa seringkali tidak ada waktu untuk mengikuti kursus yang biasanya berdurasi cukup panjang. Kendalakendala ini disambut sangat baik oleh para peserta dengan hadirnya pelatihan berbahasa Inggris ini di Rumah Siap Kerja sebagai mitra. Selama ini, belum ada program di tempat mitra yang memfokuskan kepada peningkatan keterampilan berbahasa Inggris untuk mencari kerja seperti pada kegiatan pengabdian kali ini. Pada kenyataannya, memang tidak ada lembaga manapun, bahkan kursus bahasa sekalipun yang hanya fokus pada keterampilan Bahasa Inggris secara khusus untuk memperoleh pekerjaan, kebanyakan masih berfokus pada tatanan struktur dan penggunaan bahasa Inggris secara umum di kehidupan sehari-hari. Rumah Siap Kerja sebagai mitra penyelenggaraan kegiatan mulai dari publikasi pelatihan, penyediaan tempat, penyeleksian peserta pelatihan yang disesuaikan dengan kapasitas tempat mitra, dan fasilitasi kegiatan pengabdian ini dianggap inovatif bagi para kaum muda dalam meningkatkan keterampilan kerja. Dengan terlaksananya pelatihan English for Jobseekers yang memfokuskan pada keterampilan khusus berbahasa Inggris 
dalam memperoleh pekerjaan inilah, para peserta mengapresiasi mitra yang bersedia memfasilitasi pelatihan Bahasa Inggris secara gratis ini terutama bagi peserta anak muda yang terbatas secara ekonomi dan tidak bisa mengakses kursus Bahasa Inggris yang berbayar di tempat lain.

Secara umum, pelaksanaan kegiatan pelatihan keterampilan komunikasi Berbahasa Inggris English for Jobseekers ini berjalan dengan aman dan lancar. Para peserta menunjukkan antusiasme yang sangat tinggi dalam belajar keterampilan Bahasa Inggris untuk memperoleh pekerjaan yang lebih baik. Hal ini terlihat dari kehadiran para peserta lebih awal dan tidak beranjak bahkan masih terus berkonsultasi dan diskusi dengan pemateri sekalipun pelatihan telah ditutup. Para peserta juga semangat melengkapi tugastugas yang diberikan selama sesi pelatihan mulai dari membuat CV secara daring, menuliskan CV secara konvensional, membuat surat lamaran kerja dengan metode menulis konvensional, mengirimkan surat lamaran kerja sesuai standar etika secara elektronik hingga simulasi wawancara. Semua tugas dilengkapi dengan baik dan bersedia dievaluasi oleh pemateri terutama saat sesi simulasi wawancara kerja bersama pemateri berlangsung.

Adapun beberapa tahapan kegiatan pengabdian kepada masyarakat melalui pelatihan ini terlaksana dengan kerjasama yang baik antara pemateri dan Rumah Siap Kerja sebagai mitra, rincian tahapannya adalah sebagai berikut:

1. Pemateri mendaftarkan pelatihan secara daring lewat laman resmi Rumah Siap Kerja. Setiap kegiatan yang akan dilaksanakan di Rumah Siap Kerja harus melalui prosedur pendaftaran di laman resmi untuk selanjutnya menunggu konfirmasi dari tim Rumah Siap Kerja sebagai mitra kegiatan ini.

2. Pemateri mendapatkan konfirmasi melalui surat elektronik mengenai pelatihan yang sudah didaftarkan. Konfirmasi berupa rekaman data pelatihan yang sudah didaftarkan melalui laman resmi Rumah Siap Kerja. Proses konfirmasi untuk jadwal pelaksanaan belum ditentukan di tahap ini.

3. Sehingga pemateri berinisiatif mengunjungi kantor Rumah Siap Kerja di wilayah Jakarta Selatan sebagai mitra untuk berkonsultasi dengan divisi pelatihan di Rumah Siap Kerja. Konsultasi ini dilakukan sebagai upaya akselerasi penyelenggaraan kegiatan dan koordinasi teknis pelaksanaan kegiatan agar bisa berjalan dengan baik dan lancar tanpa kendala yang berarti.

4. Pemateri dan Rumah Siap Kerja sebagai mitra berdiskusi hingga menyepakati jadwal pelaksanaan kegiatan pengabdian kepada masyarakat. Jadwal yang disepakati ini mempertimbangkan banyak hal, salah satunya waktu yang strategis bisa mendatangkan banyak peserta untuk terlibat dalam kegiatan ini.

5. Rumah Siap Kerja sebagai mitra membuatkan media promosi mengenai kegiatan pelatihan keterampilan berbahasa Inggris ini tidak hanya melalui laman resmi Rumah Siap Kerja tetapi juga di semua lini media sosial yang dikelola oleh tim Rumah Siap Kerja dimana pengikut di sosial media sudah sangat banyak sehingga penyebaran informasi kegiatan meluas secara cepat dan masif.

6. Rumah Siap Kerja juga terus mempromosikan kegiatan pelatihan ini melalui laman resmi dan media sosial resmi sehingga kegiatan ini banyak diminati oleh para calon peserta.

7. Semua calon peserta yang menunjukkan ketertarikannya di media sosial resmi Rumah Siap 
Kerja diarahkan oleh tim administrasi untuk segera mendaftarkan diri melalui laman resmi agar segera bisa mendapatkan konfirmasi untuk dapat mengikuti kegiatan pelatihan ini.

8. Rumah Siap Kerja sebagai mitra mendata para peserta yang berminat melalui borang aplikasi daring yang tersedia di laman web mitra. Semua aplikasi calon peserta terekam dengan baik di database yang diambil dari laman web resmi Rumah Siap Kerja.

9. Rumah Siap Kerja sebagai mitra menyeleksi para peserta maksimal sesuai kapasitas ruangan di Rumah Siap Kerja yang akan dipakai sebagai tempat penyelenggaraan kegiatan pelatihan ini. Adapun kapasitas maksimal untuk ruangan yang akan dipakai untuk kegiatan pelatihan ini yaitu 20 orang. Karena cukup banyak yang mendaftar, tim mitra cukup selektif untuk memilih para peserta yang akan memperoleh kesempatan mengikuti kegiatan pelatihan ini.

10. Rumah Siap Kerja sebagai mitra mengirimkan konfirmasi kepada para peserta yang terpilih untuk mengikuti kegiatan pelatihan. Tim Rumah Siap Kerja juga mengumumkan bahwa hanya peserta terpilih yang sudah dapat konfirmasi resmi dari tim administrasilah yang berhak mengikuti kegiatan pelatihan ini.

11. Rumah Siap Kerja sebagai mitra juga mendata ulang para peserta yang hadir dan mengarahkan peserta untuk masuk ke ruangan yang sudah disiapkan oleh mitra. Pada saat pelatihan belum dimulai, peserta yang hadir sudah sebanyak 15 orang dari kapasitas 20 orang yang terdiri dari kaum muda lulusan SMA/SMK/MA dan juga beberapa diantaranya baru saja menyelesaikan pendidikan di tingkat sarjana.

12. Pelatihan dimulai sesuai jadwal dan 28 peserta sudah hadir di tempat pelaksanaan kegiatan pelatihan ini. Di antara 28 peserta, ternyata ada juga beberapa peserta yang sudah bekerja dan ingin belajar untuk memperoleh kesempatan pekerjaan yang lebih baik melalui pelatihan ini.

13. Pelatihan diawali dengan pemaparan materi cara membuat CV yang tepat untuk memperbesar peluang dipilih oleh tim personalia perusahaan diantaranya $\mathrm{CV}$ harus berisi informasi yang benar, akurat, dan sesuai dengan keterampilan yang dibutuhkan oleh posisi pekerjaan dan perusahaan yang dituju. Pemateri juga memberikan borang aplikasi CV yang sesuai standar Eropa agar para peserta mengetahui bahwa CV di negara-negara Eropa terstandarisasi dalam 28 bahasa. Hal ini diajarkan agar peserta juga bisa termotivasi untuk memperoleh kesempatan bekerja atau studi ke luar negeri karena CV standar Eropa bukan hanya bisa digunakan untuk kepentingan memperoleh pekerjaan tetapi juga untuk syarat administrasi diterima studi di kampus-kampus negara Eropa. Karena pelatihan ini lebih difokuskan ke praktek, para peserta tidak hanya mendengarkan materi tetapi juga mempraktekkan penulisan CV secara konvensional di borang yang sudah dibagikan oleh pemateri. Tidak hanya praktek penulisan CV secara konvensional, para peserta juga diarahkan untuk mengisi borang CV secara elektronik terstandar Eropa di laman resmi pembuatan CV elektronik standar Eropa untuk kemudian peserta bisa mengunduh borang yang sudah diisi secara elektronik dalam bentuk dokumen yang dibutuhkan. Hal yang menarik dari laman pengisian CV standar 
Eropa ini yakni para peserta bisa sewaktu-waktu mengakses CV yang sudah dibuat untuk diperbaharui dengan informasi yang relevan dan akurat sesuai kebutuhan para peserta.

14. Setelah itu, pemateri memberikan materi surat lamaran kerja. Materi ini mencakup tentang struktur kalimat Bahasa Inggris yang tepat untuk dituliskan dalam surat lamaran kerja dimulai dari bagaimana menuliskan bagian pendahuluan, isi, hingga penutup surat dengan penggunaan kata salam penutup yang lebih tepat digunakan terutama dalam kondisi peserta mengetahui atau tidak mengetahui penerima surat yang dituju. Di era revolusi industri saat ini, surat lamaran kerja hampir semuanya tidak lagi dikirim secara konvensional ke alamat perusahaan atau instansi melainkan melalui surat elektronik. Untuk itu, materi surat lamaran kerja yang diajarkan dalam sesi ini tidak hanya dalam bentuk surat lamaran kerja tertulis atau konvensional tetapi juga secara elektronik. Ada beberapa teknik penulisan surat lamaran kerja secara elektronik yang harus diperhatikan oleh para peserta agar memperbesar peluang diterima di pekerjaan terutama pemilihan kata-kata atau diksi yang benar. Selain teknik penulisan, para peserta juga diajarkan tentang etika pengiriman surat lamaran kerja baik dengan metode konvensional maupun dengan metode elektronik. Hal ini sangat penting karena teknik penulisan yang tidak benar dan juga etika yang kurang tepat biasanya yang menjadi faktor tidak diterimanya para peserta di suatu perusahaan atau instansi untuk bekerja. Dalam sesi praktek, banyak peserta yang berkonsultasi dengan pemateri tentang kesalahan- kesalahan yang peserta pernah lakukan dalam penulisan surat lamaran kerja yang diakui mungkin menjadi faktor tidak diterimanya para peserta di posisi pekerjaan yang dituju saat itu. Pemateri mengarahkan untuk bisa lebih tepat dalam menuliskan surat lamaran kerja agar ke depannya bisa memperbesar peluang diterima bekerja di instansi atau perusahaan tertentu.

15. Setelah peserta mengetahui dan mempraktekkan materi teknik pembuatan $\mathrm{CV}$ dan surat lamaran kerja, peserta lalu dibekali dengan tips menjawab pertanyaanpertanyaan yang biasanya muncul saat sesi wawancara kerja dengan personalia perusahaan atau instansi. Pertanyaan-pertanyaan tersebut dianalisis satu per satu agar para peserta bisa memahami makna tersirat dan maksud yang sebenarnya dari pertanyaan tersebut agar para peserta bisa menjawab dengan tepat untuk memperbesar peluang diterima saat sesi wawancara dengan tim personalia nantinya. Tidak hanya teknik menjawab pertanyaan yang diajarkan tetapi juga sikap saat menjawab pertanyaan diarahkan agar nantinya para peserta bisa lebih siap dalam menghadapi wawancara kerja yang sebenarnya di masa yang akan datang.

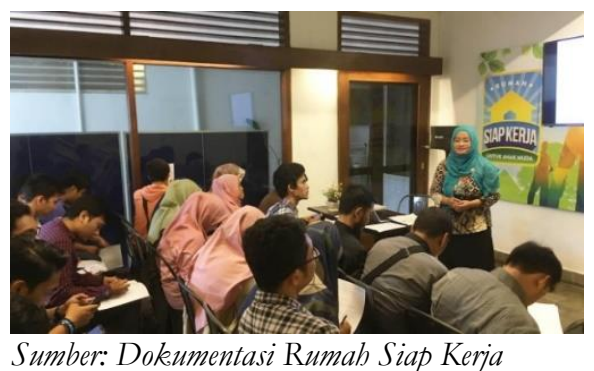

16. Setelah para peserta memahami materi juga mempraktekkan teknik bagaimana membuat $\mathrm{CV}$ dan surat 
lamaran kerja daring serta menuliskan dokumen-dokumen tersebut secara konvensional, para peserta dibagikan selembar kertas berisi daftar pertanyaan-pertanyaan yang biasanya muncul saat sesi wawancara kerja. Daftar pertanyaan ini dianalisis satu per satu untuk bisa diketahui makna tersirat dan maksud pertanyaan-pertanyaan tersebut yang sebenarnya agar nantinya para peserta bisa menjawab dengan lebih tepat dan akurat sehingga bisa memperbesar peluang memperoleh pekerjaan yang diinginkan. Para peserta menuliskan jawaban-jawaban sesuai dengan maksud pertanyaan tersebut di borang yang sudah dibagikan sebelumnya oleh pemateri. Para peserta juga diarahkan untuk berdiskusi serta mempraktekkan wawancara dengan peserta lainnya untuk saling memberikan umpan berupa koreksi dan masukan satu sama lain. Metode ini merupakan salah satu bagian dari metode peer scaffolding yang dipopulerkan oleh Vygotsky (1978) dan juga direkomendasikan oleh Clark dan Graves (2005) karena para peserta bisa saling menguatkan materi yang sudah diajarkan.

17. Sebelum memasuki sesi akhir pelatihan dimana pemateri memeriksa dan menguji langsung para peserta, pemateri mengarahkan peserta untuk juga mendiskusikan hasil tulisan mereka di borang CV, surat lamaran kerja, dan daftar jawaban sesi wawancara kerja ke sesama peserta. Setelah itu, peserta diminta mempraktekkan wawancara kerja dalam bahasa Inggris ke sesama peserta lainnya sebelum diuji oleh pemateri secara langsung di akhir sesi. Hal ini dilakukan pemateri karena beberapa penelitian (Laksmi, 2006; Santoso, 2010;
Rezaei \& Shokrpour, 2011; Azir, 2019) sudah menunjukkan bahwa metode saling memberikan umpan yang juga bagian dari metode peer scaffolding (Vygotsky, 1978) ini efektif dalam peningkatan keterampilan penulisan dan keterampilan berbicara pembelajar Bahasa Inggris sebagai bahasa asing. Hal ini juga terbukti di sesi akhir saat pemateri menguji wawancara secara langsung dimana para peserta sudah lebih baik setelah banyak diberi masukan dan tanggapan dari sesama peserta lain.

Di sesi akhir, pemateri memanggil para peserta satu per satu untuk simulasi wawancara kerja. Pemateri bertindak sebagai personalia perusahaan yang mewawancarai para peserta. Dalam sesi praktek ini, pemateri secara langsung memilih dan mengajukan pertanyaan-pertanyaan yang sering muncul pada wawancara kerja untuk menguji seberapa paham para peserta terhadap acuan dan standar yang sudah diberikan sebelumnya oleh pemateri. Penguji juga memberikan masukan pada CV dan surat lamaran kerja yang juga sudah banyak diberi koreksi dan masukan oleh sesama peserta lainnya sebelum para peserta mulai praktek wawancara kerja dengan pemateri.

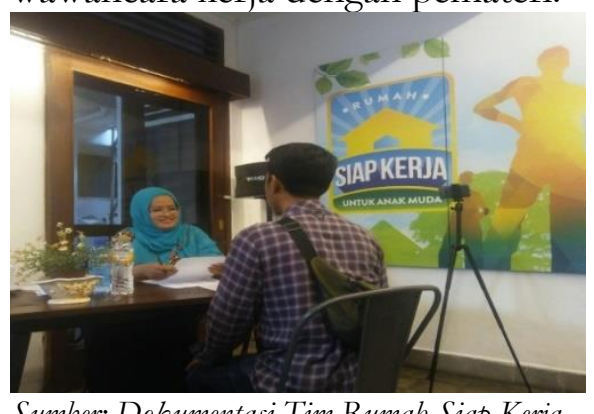

Sumber: Dokumentasi Tim Rumah Siap Kerja

Setelah sesi pelatihan, Rumah Siap Kerja sebagai mitra meminta para peserta untuk mengisi borang evaluasi pelatihan keterampilan berbahasa Inggris. Pada 
kesempatan ini, peserta bisa memberikan evaluasi penilaian dari kegiatan pelatihan untuk perbaikan ke depan. Hasil evaluasi menunjukkan bahwa para peserta menilai kegiatan pengabdian ini seharusnya diadakan kembali dengan jangka waktu yang lebih lama dan lebih intens.

\section{KESIMPULAN}

Kegiatan pengabdian kepada anak muda sebagai objek masyarakat dalam kegiatan pelatihan ini dilaksanakan dengan fokus pada 3 materi: CV, surat lamaran kerja, dan wawancara kerja. Kegiatan pengabdian ini diawali dengan diskusi antara pemateri dan peserta pelatihan sehingga pemateri mendapatkan gambaran materi secara umum terkait kemampuan Bahasa Inggris dalam mencari kerja. Metode ceramah, diskusi, praktek, dan evaluasi dilakukan sebagai upaya penyampaian materi kepada para peserta secara optimal. Dengan metode ini, para peserta juga secara aktif dan inisiatif mendapatkan pengetahuan dan pengalaman belajar dari simulasi yang dilakukan selama pelatihan berlangsung. Kegiatan pengabdian kepada masyarakat melalui metode pelatihan keterampilan berbahasa Inggris ini diharapkan bisa diselenggarakan dengan durasi yang lebih lama agar manfaat dari ilmu yang dibagikan oleh pemateri bisa dinikmati anak muda lainnya secara lebih maksimal.

\section{DAFTAR PUSTAKA}

Al-Sibai, D. (2004). Promoting oral fluency of second language learners. Retrieved on October, 13.

Aungwatanakun, S. (1994) English Teaching Methodology, (2nd), Bangkok: Chulalongkorn University Press.

Azir, I. D. A. (2019). Applying Peer Scaffolding to Enhance the EFL Vocational Students' Speaking Skills. Ethical Lingua: Journal of Language Teaching and Literature, 6(2), 149-157.

Bps.go.id. (2019). Badan Pusat Statistik. [online] Available at: https://www.bps.go.id/pressrelease/2 018/11/05/1485/agustus-2018-tingkat-pengangguran-terbuka--tpt-sebesar-5-34-persen.html [Diakses 24 Jul. 2019].

Di Gropello, E., Kruse, A., \& Tandon, P. (2011). Skills for the labor market in Indonesia: trends in demand, gaps, and supply. The World Bank.

Laksmi, E. D. (2006). " SCAFFOLDING" STUDENTS'WRITING IN EFL CLASS: IMPLEMENTING PROCESS APPROAC. TEFLIN Journal, 17(2), 144-156.

Lie, A. (2007). Education policy and EFL curriculum in Indonesia: Between the commitment to competence and the quest for higher test scores. TEFLIN journal, 18(1), 01-15.

Rezaei, M., \&Shokrpour, N. (2011). Teacher Vs. Peer Scaffolding Modes in L2 Writing Classes: a Consideration of Genre Approach to Writing. Indonesian JELT, 7(2), 40-64.

Richards, J. C. (2008). Teaching listening and speaking. Cambridge, England: Cambridge university press.

Santoso, A. (2010). Scaffolding an EFL (English as a foreign language) 'effective writing class in a hybrid learning community (Doctoral dissertation, Queensland University of Technology). 